\title{
Dampak Pandemi Covid 19 Terhadap Pergerakan Indeks Saham: Studi Kasus Pasar Saham Syariah Indonesia
}

\author{
Nurfitri Martaliah ${ }^{1)}$ \\ Salmia ${ }^{2)}$ \\ Puji Wahyuli ${ }^{3)}$ \\ Muhammad Habibullah Aminy ${ }^{4}$ \\ Ahmad Suhendri5) \\ STAI Ahsanta Jambi ${ }^{1), 2), ~ \& ~ 3) ~}$ \\ Universitas Islam Al-Azhar4) \& 5) \\ 1)Email: nmartaliah@yahoo.com \\ ${ }^{2}$ Email: Salmiaumy@ gmail.com \\ 3)Email: Puji.wahyuli0787@ gmail.com \\ 4)Email: Habibamin22@ gmail.com \\ 5)Email: hendryfe@yahoo.com
}

\begin{abstract}
The Islamic capital market is one of the financial investment instruments that also serves to meet the needs of Muslim investors to invest according to sharia in a country. The Islamic capital market in recent years has experienced quite good growth in Indonesia, with various instruments in accordance with the needs and desires of the majority of Muslims, and has the opportunity to create a fair redistribution of the income and wealth ecosystem. But there are pandemic cases that occur 19 so that all financial and economic instruments face obstacles including the Islamic capital market. This study aims to look at the impact of a pandemic on the movement of Islamic stock indexes in Indonesia using a literature study approach or looking for primary information from capital market development data that is released regularly on the official website and also information from other media. The results of research analysis by looking at data and analysis of other simple trends conclude that in the following months during the covid pandemic 19 will continue to decline in the movement of stock indexes, if the covid 19 pandemic problem is not resolved properly, stock movements will decline and endanger the Indonesian economy. So there is no concrete need to overcome this problem so that it does not become an economic recession.
\end{abstract}

Keywords: Capital market Syariah, Pandemic, Covid 19, Stock.

\section{PENDAHULUAN}

Perkembangan sektor keuangan syariah saat ini mengalami pertumbuhan yang pesat. Di antara indikator perkembangan tersebut adalah meningkatnya kebutuhan terhadap 
Jurnal Kompetitif : Media Informasi Ekonomi Pembangunan, Manajemen dan Akuntansi Vol. 6 No. 2, September 2020

berbagai fasilitas instrumen-instrumen keuangan yaitu perbankan syariah maupun lembaga keuangansyariah nonbank khususnya setelah terjadi krisis keuangan global 2007/2008. ${ }^{1}$

Hal ini juga dikarenakan mayoritas penduduk Indonesia adalah muslim, untuk memenuhi kebutuhan pemodal muslim yang ingin bertransaksi berdasarkan prinsip-prinsip syariah. Salah satu lembaga keuangan yang cukup strategis dalam lintas sistem keuangan saat ini adalah Pasar Modal yang menawarkan berbagai instrumen investasi keuangan. Di samping instrumen-instrumen keuangan konvensional, saat ini juga sudah ditawarkan sejumlah instrumen keuangan pasar modal yang memenuhi ketentuan syariah yaitu pasar modal syariah. Sejumlah bursa efek dunia telah menyusun indeks yang secara khusus terdiri dari komponen saham-saham yang tergolong kegiatan usahanya tidak bertentangan dengan prinsip syariah. ${ }^{2}$

Perkembangan Pasar modal syariah dimulai pada tahun 1997, proses perkembangan pasar modal syariah melewati Tragedi krisis ekonomi pada 1998 di Indonesia, dan saat ini terjadi kembali krisis ekonomi Pada Bulan Maret 2020 awal hingga saat ini karena adanya penurunan harga minyak yang berimpas pada penurunan pertumbuhan ekonomi dunia bahkan Indonesia. $^{3}$

Indonesia memulai peperangan untuk menghadapi pandemi Corona Virus Disease (Covid-19) yang mulai masuk di Indonesia. Dengan masuknya pertama kali Covid-19 di Indonesia memberikan dampak secara tidak langsung untuk negara Indonesia yang paling terasa adalah dampak dari Perekonomian dari negera Indonesia. ${ }^{4}$

Menurut Menteri Keuangan Sri Mulyani bahwa penyebaran Covid - 19 yang masif di Indonesia membuat penurunan pada kegiatan ekonomi. ${ }^{5}$ Itu terjadi pada berbagai sektor lembaga keuangan di Indonesia seperti perbankan hingga konsumsi rumah tangga

\footnotetext{
1 Ali Rama, (2013) Perbankan Syariah Dan Pertumbuhan Ekonomi Indonesia, Uin Syarif Hidayatullah Jakarta, Signifikan Vol. 2 No. 1 April 2013. Hal 34

${ }^{2}$ muhammad Yafiz, (2008) Saham Dan Pasar Modal Syariah: Konsep, Sejarah Dan Perkembangannya.Fakultas Syariah Iain Sumatera Utara, Miqot Vol. Xxxii No. 2 Juli-Desember 2008 .Hal. 233

${ }^{3}$ Ratna Iskana, Harga Minyak Indonesia Maret Anjlok Hampir 40\% Tertekan Krisis Corona, Https://Katadata.Co.Id/Berita/2020/04/02/Harga-Minyak-Indonesia-Maret-Anjlok-Hampir-40Tertekan-Krisis-Corona Di Akses 5 Mei 2020 Pukul 21.00 Wib

${ }^{4}$ Https://Idcloudhost.Com, Di Akses 26 Maret 2020

${ }^{5}$ Dwi Aditya Putra, Ekonomi Indonesia Diprediksi Baru Pulih Dari Corona Pada 2021, Https://Www.Liputan6.Com/Bisnis/Read/4216385/Skenario-Terburuk-Dampak-Corona-EkonomiIndonesia-Tumbuh-Negatif-04-Persen, Di Akses 5 Mei 2020
} 
Jurnal Kompetitif : Media Informasi Ekonomi Pembangunan, Manajemen dan Akuntansi Vol. 6 No. 2, September 2020

yang menurun. "Konsumsi rumah tangga turun, bisa mencapai 2,60 persen, termasuk investasi juga turun. Selanjutnya yang terjadi di sektor perbankan dan perusahaan pembiayaan berpotensi mengalami persoalan likuiditas. Sehingga menyebabkan depresiasi rupiah volatilitas pasar keuangan dan capital flight.

Pandemi Covid - 19yang terus menyebar membuat transaksi jual terjadi di bursa saham global. Lebih dari 150 negara terpapar COVID-19, memasuki level dari 217.000 orang, dengan 8.800 orang meninggal dunia.Banyak negara kini menerapkan kebijakan lockdown, aktivitas ekonomi menjadi menurun drastis, dan pertumbuhan ekonomi berisiko melambat, bahkan terancam mengalami resesi global. Akibatnya aksi jual di bursa saham global tak terhindarkan. ${ }^{6}$

Perdangangan Ritel dan Non Ritel di awal akhir 2019 di prediksi merupakan bisnis yang prospektif yang mulai menjamur dan menguntungkan untuk sebagian besar masyarakat. ${ }^{7}$ Namun setelah kejadian atau masuknya Pandemi Covid 19 di beberapa Negara hal ini mengakibatkan bayak perusahan ritel dan non ritel yang mengalami kemerosotan bahkan yang terpaksa mem PHK karyawan karna tidak mendapatkan keuntungan sama sekali sedangkan modal usaha harus tetap berjalan.

${ }^{6}$ Https://Www.Cnbcindonesia.Com, Ihsg Ambles Ke Bawah 4.100 Di Sesi I, 7 Saham Kena Arb Diakses 20 Maret 2020.

${ }^{7} \mathrm{Https}: / /$ Www.Sentrarak.Com, Diakses 10 Mei 2020. 
Jurnal Kompetitif : Media Informasi Ekonomi Pembangunan, Manajemen dan Akuntansi Vol. 6 No. 2, September 2020

\section{Tabel 1: Kapitalisasi Pasar Bursa Efek Indonesia \\ Tahun 2000-2020}

\section{KAPITALISASI PASAR BURSA EFEK INDONESIA}

(Rp Miliar)

\begin{tabular}{|c|c|c|c|c|}
\hline & TAHUN & JAKARTA ISLAMIC INDEX & $\begin{array}{l}\text { INDEKS SAHAM SYARIAH } \\
\text { INDONESIA }\end{array}$ & $\begin{array}{l}\text { JAKARTA ISLAMIC } \\
\text { INDEX } 70\end{array}$ \\
\hline 2000 & & $74.268,92$ & - & - \\
\hline 2001 & & $87.731,59$ & - & - \\
\hline 2002 & & $92.070,49$ & - & - \\
\hline 2003 & & $177.781,89$ & - & - \\
\hline 2004 & & $263.863,34$ & - & - \\
\hline 2005 & & $395.649,84$ & - & - \\
\hline 2006 & & $620.165,31$ & - & - \\
\hline 2007 & & $1.105 .897,25$ & - & - \\
\hline 2008 & & $428.525,74$ & - & - \\
\hline 2009 & & $937.919,08$ & - & - \\
\hline 2010 & & $1.134 .632,00$ & - & - \\
\hline 2011 & & $1.414 .983,81$ & $1.968 .091,37$ & - \\
\hline 2012 & & $1.671 .004,23$ & $2.451 .334,37$ & - \\
\hline 2013 & & $1.672 .099,91$ & $2.557 .846,77$ & - \\
\hline 2014 & & $1.944 .531,70$ & $2.946 .892,79$ & - \\
\hline 2015 & & $1.737 .290,98$ & $2.600 .850,72$ & - \\
\hline 2016 & & $2.035 .189,92$ & $3.170 .056,08$ & - \\
\hline 2017 & & $2.288 .015,67$ & $3.704 .543,09$ & - \\
\hline 2018 & & $2.239 \cdot 507,78$ & $3.666 .688,31$ & $2.715 .851,74$ \\
\hline 2019 & & $2.318 .565,69$ & $3.744 .816,32$ & $2.800 .001,49$ \\
\hline 2020 & Januari & $2.134 .960,15$ & $3.464 .489,36$ & $2.574 .301,02$ \\
\hline
\end{tabular}

Sumber : $\underline{w w w . o j k . c o m}$

Dari tabel 1 menunjukkan perkembangan saham syari'ah sebelum pandemic covid 19 memasuki Indonesia. Ini bisa dilihat dari jumlah transaksi saham syari'ah dari tahun 2000-2019. Saham syariah tercatat kinerja yang baik hingga tahun 2019. Dukungan dari Wakil presiden Ma'ruf Amin Meminta Asosiasi Emiten Perkuat Pasar Modal Syariah di tahun 2019 karena melihat potensi yang dimiliki, Keuangan syariah akan menciptakan ekosistem redistribusi pendapatan dan kekayaan secara adil. Pada ujungnya menciptakan ekonomi dan kesejahteraan.Optimisme ini disampaikan langsung oleh Ma'ruf Amin di Bursa Efek Indonesia Jakarta.

Pada tanggal 31 desember 2019, Jakarta Islamis Index (JII) tercatat naik 1,88\%, indeks Indonesia Sharia Stock Index (ISSI) naik 2,03\%, dan indeks Jakarta Islamic Index 70 (JII70) naik 2,56\%. Sementara, IHSG sepanjang tahun 2019 bertumbuh 1,70\%. Menurut Artha Sekuritas Nugroho Rahmat Fitriyanto bahwa kondisi tersebut disebabkan oleh 
Jurnal Kompetitif : Media Informasi Ekonomi Pembangunan, Manajemen dan Akuntansi Vol. 6 No. 2, September 2020

neraca perusahaan anggota indeks syariah yang pada umumnya lebih sehat dibanding perusahaan lain. Sehingga, pertumbuhan saham-saham syariah terlihat lebih baik. Dengan kondisi makroekonomi yang belum cukup stabil di 2019, investor cenderung mencari saham-saham defensif dengan neraca kuat serta tingkat utang yang rendah. ${ }^{8}$

Berdasarkan latar belakang di atas, penulis berpendapat bahwa Pandemi Virus Covid-19 berdampak pada harga saham syariah. Maka rumusan masalah yang dapat diambil sebagai kajian dalam penelitian ini adalah Bagaimana Dampak Pandemi Covid 19 Terhadap Indeks Saham Syariah Indonesia?

\section{METODE PENELITIAN}

Jenis penelitian yang digunakan dalam pengumpulan data ini adalah jenis pengumpulan studi kepustakaan (library research)dimana dalam hal ini penulis mengumpulkan data-data dari buku-buku, media sosial, artikel, karya ilmiah yang ada relevansinya dengan permasalahan yang dibahas. Mengemukakan bahwa yang dimaksud dengan "Studi kepustakaan adalah teknik pengumpulan data dengan mengadakan studi penelaahan terhadap buku-buku, literature-literatur, catatan-catatan, dan laporan-laporan yang ada hubungannya dengan masalah yang dipecahkan. ${ }^{9}$

Penelitian kepustakaan merupakan jenis penelitian kualitatif yang pada umumnya tidak terjun ke lapangan dalam pencarian sumber datanya. Penelitian kepustakaan merupakan metode yang digunakan dalam pencarian data, atau cara pengamatan (bentuk observasi) secara mendalam terhadap tema yang diteliti untuk menemukan 'jawaban sementara' dari masalah yang ditemukan di awal sebelum penelitian ditindaklanjuti. Dengan kata lain penelitian kepustakaan merupakan metode dalam pencarian, mengumpulkan dan menganalisi sumber data untuk diolah dan disajikan dalam bentuk laporan penelitian kepustakaan.

\footnotetext{
${ }^{8}$ Https://Investasi.Kontan.Co.Id, Diakses 31 Desember 2019

${ }_{9}^{9}$ M. Nazir, Metode Penelitian, (Jakarta, Ghalia Indonesia, cet.ke-5, 2003), Hal 27
} 


\section{PASAR SAHAM SYARIAH INDONESIA PASCA COVID-19}

\section{Gambar1: Grafik IHSG dan Nilai Rata-Rata Perdagangan Harian}

Per Bulan 2015-17 April 2020

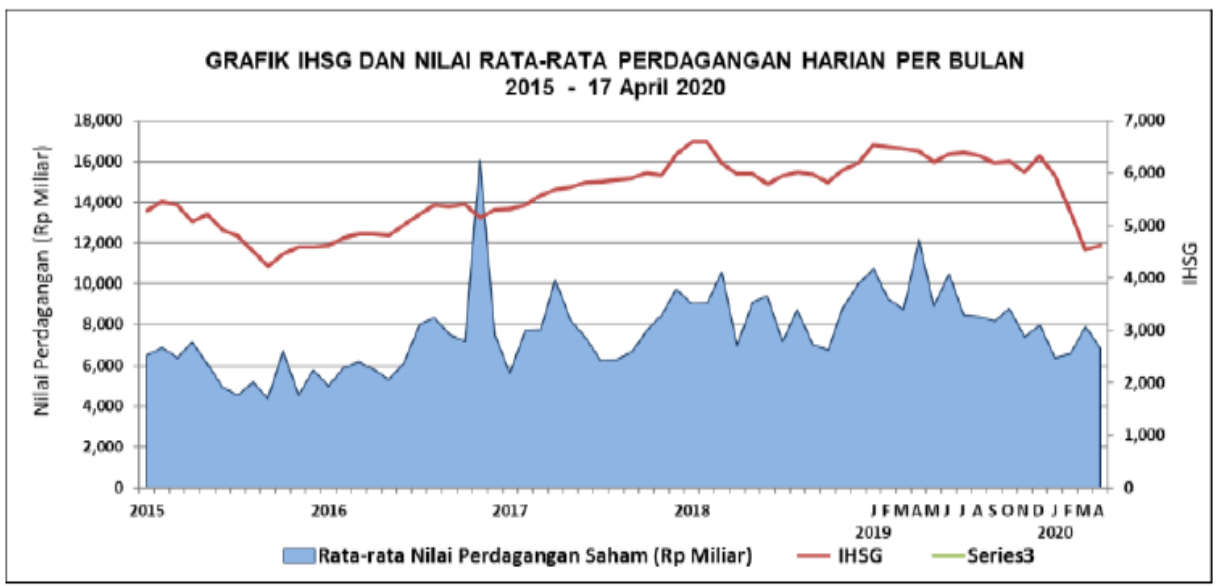

Sumber : Ojk.com

Dari gambar Data grafik IHSG di atas pada tahun 2020 dapat ditarik analisis bahwa terjadi penuruan yang sangat signifikan di bandingkan dengan beberapa bulan kebelakang yang memiliki grafik pertumbuhan yang stabil di pasar perdaganagan saham.Berdasarkan data Bursa Efek Indonesia per Oktober 2019, jumlah investor syariah tercatat sebanyak 62.840, naik 41\% dari posisi pada akhir tahun 2018 lalu sebanyak 44.536 investor. $^{10}$ Tentulah melihat grafik ini terjadi penurunan yangmembuatpara stakeholder pasar modal syariah di awal tahun 2020 ini turun. Karena terjadinya Demand shock dan supply shock, Serta Penurunan konsumsi Rumah Tangga (RT) yakni sektorsektor yang terdampak kuat. ${ }^{11}$

Kasus pemecatan Karyawan disalah satu pusat perbelanjaan yakni Ramayana yang juga merupakan perusahaan ritel yang cukup mumpuni di Indonesia dan banyak mempekerjakan karyawan memperburuk pergerakan saham di Indonesia. Covid 19 memperburuk daya beli masyarakat dan imbasnya terjadi di banyak perusahaan ritel yang nilai perdangangannya mengalami penurunan karena pola konsumen yang mengubah

\footnotetext{
${ }^{10}$ Market.bisnis.com, 2020.

${ }^{11}$ Makalah Presentasi Azis Budi Setiawan (Dosen Stei Sebi), Pandemic Covid Dan Umkm
} 
Jurnal Kompetitif : Media Informasi Ekonomi Pembangunan, Manajemen dan Akuntansi Vol. 6 No. 2, September 2020

transaksi dari luring menjadi Daring serta persaingan sesamaperitel itu sendiri. ${ }^{12}$ Kedepan pergerakan ekonomi Indonesia akan semakin melambat akibat dari wabah ini beberapa perusahaan besar terus menambah deretan karyawan yang ter PHK, yang mana perusahan ini bergerak di bidang Tour \& Travel, Pusat perbelanjaan, Restauran, Hotel/ tempat penginapan, sebagian besar usaha bisnis terutama yang berkaitan dengan pariwisata. ${ }^{13}$ PHK merupakan langkah terakhir yang banyak dilakukan oleh para pengusaha untuk meminimalisir kerugian perusahaan.

Hal ini sangat merugikan semua pihak terutama ekonomi Negara yang berhubungan langsung dengan keberlangsungan masyarakat luas dan problem ini di prediksi akan berlangsung sampai akhir 2020. ${ }^{14}$ Mengingat pandemic Covid 19 yang di prediksi berakhir di bulan September. Beberapa perusahaan yang memiliki trading di pasar modal mem PHK banyak karyawan bahkanInformasi yang didapat daridetik news.com bahwa tejadi 3 juta karyawan yang di PHK selama kasus pandemi Covid-19. ${ }^{15}$ ini dan akan terus meningkat jika problem pandemi ini belum teratasi. Seharusnya di masa Ramadhan dan mendekati libur semester seperti ini jasa transportasi dan bisnis yang bergerak dalam bidang kuliner, pariwisata dan pusat perbelanjaan banyak mengalami kenaikan karna minat konsumen yang meningkat, namun hal ini berubah drastis akibat pandemi covid yang sampai saat ini belum ada penanganan yang signifikan untuk memperbaiki pergerakan pasar ritel \& non ritel di Indonesia.

\footnotetext{
${ }^{12}$ Https://Voi.Id/Artikel/Baca/4795/Phk-Ramayana-Dan-Anjloknya-Harga-Saham-Emiten-Berkode-RalsTersebut, Di Akses 5 Mei 2020 Pukul 22.00 Wib

${ }^{13}$ Https://Www.Kompas.Com/Tren/Read/2020/05/08/152300365/Airy-Tutup-Ini-Daftar-6-Perusahaan-YangPhk-Karyawan-Karena-Corona-?Page $=3$

${ }^{14}$ Https://M.Detik.Com/Health/Berita-Detikhealth/D-5003007/Prediksi-Akhir-Wabah-Corona-MundurIndonesia-Jadi-23-September Di Akses 3 Mei 2020 Pukul 22.00 Wib

${ }^{15}$ Https://News.Detik.Com/Berita/D-5007794/3-Juta-Pekerja-Kena-Phk-Kemnaker-Buat-Program-PadatKarya, Di Akses 4 Mei 23.00 Wib
} 
Jurnal Kompetitif : Media Informasi Ekonomi Pembangunan, Manajemen dan Akuntansi Vol. 6 No. 2, September 2020

\section{Tabel 2: Rekapitulasi Nilai Perdagangan Saham Berdasarkan Tipe Investor}

\begin{tabular}{|c|c|c|c|c|c|c|c|c|}
\hline \multirow{3}{*}{ Periode } & \multicolumn{5}{|c|}{ REKAPITULASI NILAI PERDAGANGAN SAHAM BERDASARKAN TIPE INVESTOR } & \multicolumn{3}{|c|}{ dalam Rp miliar } \\
\hline & \multirow{2}{*}{ Total Nilai } & \multicolumn{2}{|c|}{ Domestik } & \multicolumn{2}{|c|}{ Asing } & \multirow{2}{*}{ Net Beli Asing } & \multicolumn{2}{|c|}{ Kontribusi Investor (\%) } \\
\hline & & Beli & Jual & Beli & Jual & & Domestik & Asing \\
\hline 2015 & $1,406,362.37$ & $810,032.91$ & $787,443.87$ & $596,329.46$ & $618,918.49$ & $(22,589.04)$ & 56.79 & 43.21 \\
\hline 2016 & $1,844,587.57$ & $1,156,095.46$ & $1,172,264.96$ & $688,492.11$ & $672,322.62$ & $16,169.49$ & 63.11 & 36.89 \\
\hline 2017 & $1,809,592.19$ & $1,166,645.78$ & $1,126,776.63$ & $642,946.41$ & $682,815.56$ & $(39,869.15)$ & 63.37 & 36.63 \\
\hline 2018 & $2,040,086.34$ & $1,311,149.62$ & $1,260,403.78$ & $728,936.73$ & $779,682.56$ & $(50,745.84)$ & 63.03 & 36.97 \\
\hline 2019 & $2,230,919.17$ & $1,482,994.30$ & $1,532,189.48$ & $747,924.87$ & $698,729.69$ & $49,195.18$ & 67.58 & 32.42 \\
\hline 2020 & $520,349.84$ & $318,193.38$ & $303,322.87$ & $202,156.45$ & $217,026.96$ & $(14,870.51)$ & 59.72 & 40.28 \\
\hline Januari & $140,066.98$ & $91,470.63$ & $91,504.21$ & $48,596.36$ & $48,562.78$ & 33.58 & 65.32 & 34.68 \\
\hline Februari & $131,391.61$ & $77,565.83$ & $72,808.81$ & $53,825.77$ & $58,582.80$ & $(4,757.02)$ & 57.22 & 42.78 \\
\hline Maret & $166,003.93$ & $95,628.28$ & $90,037.35$ & $70,375.65$ & $75,966.58$ & $(5,590.93)$ & 55.92 & 44.08 \\
\hline April & $82,887.32$ & $53,528.65$ & $48,972.50$ & $29,358.67$ & $33,914.81$ & $(4,556.14)$ & 61.83 & 38.17 \\
\hline $6-9 \mathrm{Apr}$ & $29,961.61$ & $20,645.08$ & $18,784.22$ & $9,316.54$ & $11,177.40$ & $(1,860.86)$ & 65.80 & 34.20 \\
\hline $13-17 \mathrm{Apr}$ & $32,415.50$ & $20,638.53$ & $18,413.89$ & $11,776.98$ & $14,001.61$ & $(2,224.63)$ & 60.24 & 39.76 \\
\hline $13 \mathrm{Apr}$ & $5,461.75$ & $3,054.70$ & $3,377.55$ & $2,407.05$ & $2,084.20$ & 322.85 & 58.88 & 41.12 \\
\hline $14 \mathrm{Apr}$ & $6,028.83$ & $4,066.24$ & $3,639.02$ & $1,962.59$ & $2,389.81$ & (427.22) & 63.90 & 36.10 \\
\hline $15 \mathrm{Apr}$ & $7,013.64$ & $4,598.65$ & $4,225.42$ & $2,414.99$ & $2,788.22$ & (373.23) & 62.91 & 37.09 \\
\hline $16 \mathrm{Apr}$ & $6,535.44$ & $4,352.66$ & $3,157.94$ & $2,182.78$ & $3,377.51$ & $(1,194.73)$ & 57.46 & 42.54 \\
\hline $17 \mathrm{Apr}$ & $7,375.84$ & $4,566.28$ & $4,013.97$ & $2,809.56$ & $3,361.87$ & (552.31) & 58.16 & 41.84 \\
\hline
\end{tabular}

Sumber : Ojk.com

Kasus penurunan perdagangan Saham sangat jelas terlihat dari tabel 2 di atas, sebagaimana yang sudah di paparkan di awal.Bahkan saham yang di miliki dan di beli oleh asing jauh lebih rendah dibandingkan yang domestik, berarti sudah ada kesadaran dari masyaraka lokal untuk sadar berinvesatasi dalam saham domestik untuk perekonomian domestik. Sebenarnya bagipengusaha atau individu yang usaha atau pendapatannya tidak mengalami perubahan akibat dari Covid-19, penurunan harga saham di pasaran merupakan kesempatan bagi masyarakat untuk melakukan investasi saham yang harganya mengalami penurunan. Chief Investment Officer Jagartha Advisors Erik Argasetya dalam Bisnis.com menyebut kondisi penurunan pasar saham saat ini sebagai diskon besar-besaran, sehingga memberi peluang para investor untuk membangun portofolionya dan mendapatkan keuntungan. Lebih lanjut Erik mengatakan "Jika dilihat secara jangka panjang pun, pasar saham akan selalu rebound setelah adanya epidemi. Sehingga dengan kondisi pasar terkini, investor dapat memanfaatkan situasi untuk membeli produk saham karena harga saham yang rendah dan membiarkannya hingga kondisi pasar membaik 
Jurnal Kompetitif : Media Informasi Ekonomi Pembangunan, Manajemen dan Akuntansi Vol. 6 No. 2, September 2020

Banyaknya isu mengakibatkan Indeks Harga Saham Gabungan (IHSG) telah terkoreksi sekitar 30\% sejak awal tahun 2020 (ytd). Bahkan, dalam beberapa waktu terakhir IHSG telah mengalami beberapa kali suspensi perdagangan sementara karena mengalami pelemahan hingga $-5 \%$ dalam sehari. ${ }^{16}$ Bahkan dalam Tabel Gambar di atas menunjukkan total Net Beli Asing minus d angka 5.590,93.

Tabel 3: Harga Saham

\begin{tabular}{|c|r|r|l}
\hline Periode & \multicolumn{1}{l|}{ IHSG } & \multicolumn{1}{c|}{ LQ45 } & \multicolumn{1}{l}{ III } \\
\hline 2015 & $4,593.01$ & 792.03 & 603.35 \\
2016 & $5,296.71$ & 884.62 & 694.13 \\
2017 & $6,355.65$ & $1,079.39$ & 759.07 \\
2018 & $6,194.50$ & 982.73 & 685.22 \\
2019 & $6,299.54$ & $1,014.47$ & 698.09 \\
\hline 2020 & $4,634.82$ & 695.47 & 497.01 \\
\hline Januari & $5,940.05$ & 961.98 & 642.80 \\
Februari & $5,452.70$ & 879.53 & 565.01 \\
Maret & $4,538.93$ & 691.13 & 476.39 \\
April & $4,634.82$ & 695.47 & 497.01 \\
\hline 6 - 9 Apr & $4,649.08$ & 700.06 & 498.02 \\
13 - 17 Apr & $4,634.82$ & 695.47 & 497.01 \\
\hline & & & \\
\hline 13 Apr & $4,623.89$ & 693.48 & 495.79 \\
14 Apr & $4,706.49$ & 712.26 & 508.28 \\
15 Apr & $4,625.91$ & 694.44 & 496.42 \\
16 Apr & $4,480.61$ & 662.69 & 476.30 \\
17 Apr & $4,634.82$ & 695.47 & 497.01 \\
\hline
\end{tabular}

Sumber : ojk.com

Terjadinya penurunan perdagangan saham di 2020 khususnya di bulan maret. Sedangkan di bulan april sudah mulai terjadi kenaikan walaupun belum bisa di pastikan apakah akan terus membaik atau bahkan akan semakin memburuk melihat keadaaan pasar yang semakin tidak menentu. Adapun dampak yang dirasakan dan dapat dilihat dari penyebaran Covid -19 terhadap aktivitas ekonomi dan bisnis syariah termasuk pasar saham

${ }^{16}$ Https://Finansial.Bisnis.Com/Read/20200329/55/1219348/Strategi-Investasi-Di-Tengah-Pandemi-VirusCorona Di Akses Pada 04 Mei 2020 Pukul 05.00 Wib 
Jurnal Kompetitif : Media Informasi Ekonomi Pembangunan, Manajemen dan Akuntansi Vol. 6 No. 2, September 2020

syariah yakni; ${ }^{17}$ Tingkat kunjungan wisatawan asing dan domestik merosot drastis bahkan bisa di bilang nihil,Tingkat okupansi hotel turun 10-50 persen, termasuk hotel-hotel syariah, penjualan paket-paket wisata bahkan berhenti biro travel mengalami dan menanggung kerugian cukup besar akibat banyaknya perjalanan umrah dan perjalanan haji ke Mekkah di tunda. Penurunan aktivitas konsumsi masyarakat telah mulai terjadi pada produk non bahan pokok termasauk makanan dan minuman halal kosmetik dan fashion muslim.

Adapun untuk melihat apakah akan terjadi Trend kenaikan atau penurunan perdagangan Saham di bulan Mei 2020 hingga Desember 2020 maka peneliti melakukan pengolahan data dengan menyesuaikan data yang sudah ada.Hasil pengolahan data yang di tampilkan di bawah ini hanya merupakan prediksi dengan menggunakan instrument pengolahan data dan bukan merupakan hal yang pasti terjadi.

Tabel 4 : Hasil Analisis Trend Perdagangan Saham

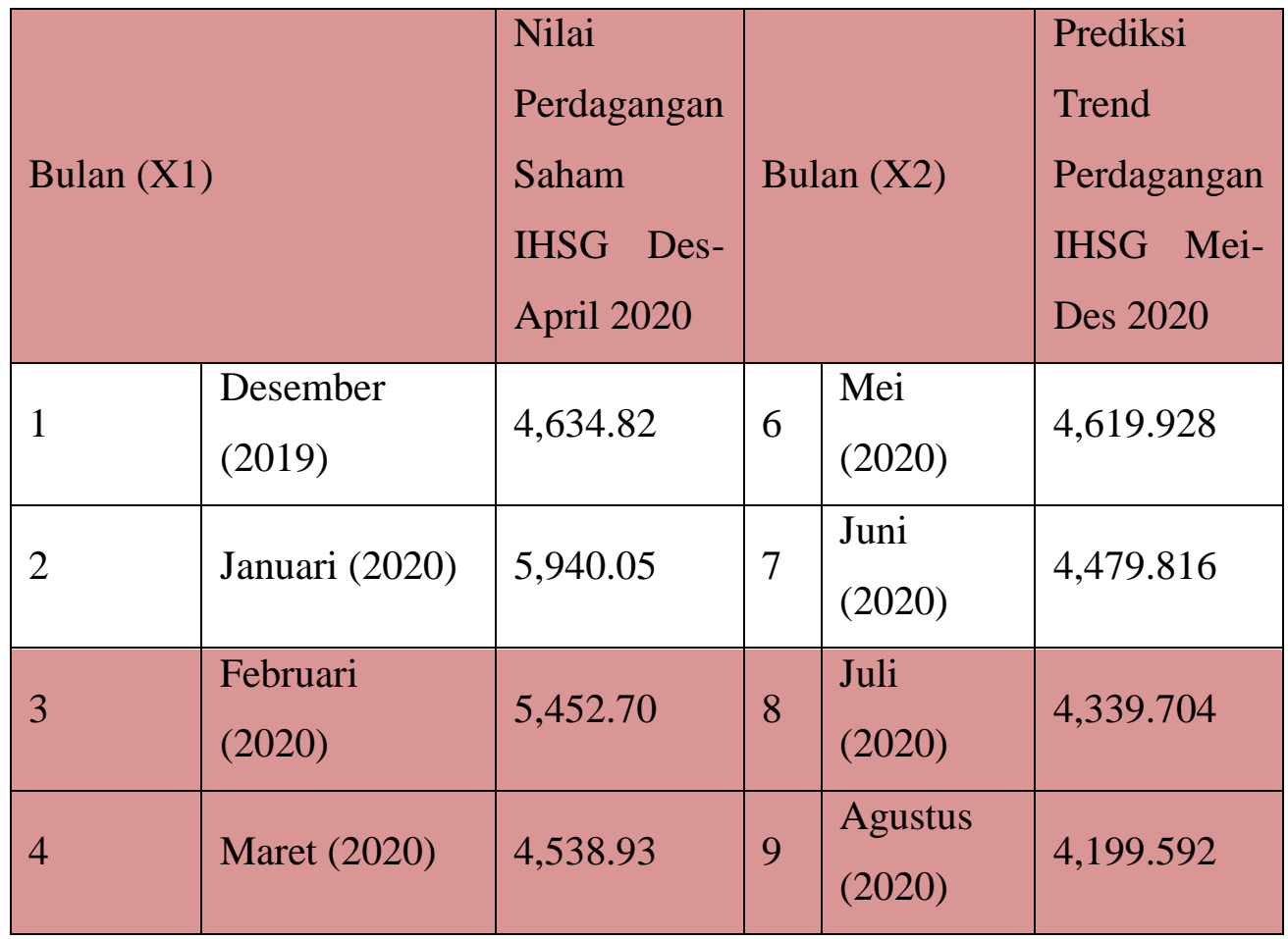
${ }^{17} \mathrm{Https}: / /$ Money.Kompas.Com/Read/2020/04/01/192000226/Covid-19-Dan-Bisnis-Syariah,
Mei 2020 Pukul 05.00 Wib 
Jurnal Kompetitif : Media Informasi Ekonomi Pembangunan, Manajemen dan Akuntansi Vol. 6 No. 2, September 2020

\begin{tabular}{|l|l|l|l|l|l|}
\hline 5 & April (2020) & $4,634.82$ & 10 & $\begin{array}{l}\text { September } \\
(2020)\end{array}$ & $4,059.48$ \\
\hline & & 11 & $\begin{array}{l}\text { Oktober } \\
(2020)\end{array}$ & $3,919.368$ \\
\hline & 12 & $\begin{array}{l}\text { November } \\
(2020)\end{array}$ & $3,779.256$ \\
\hline & 13 & $\begin{array}{l}\text { Desember } \\
(2020)\end{array}$ & $3,639.144$ \\
\hline
\end{tabular}

Sumber : Data diolah, 2020

Dari tabel 4 hasil analisis Trend sederhana di atas penulis menyimpulkan bahwa pada bulan-bulan berikutnya di masa Pandemi Covid 19 akan terus terjadi penurunan Perdagangan Saham, jika permasalahan Covid 19 ini tidak teratasi dengan baik maka penurunan pergerakan indeks saham di Indonesia baik saham syariah akan mengalami penurunan dan membahayakan perekonomian Indonesia. Harapannya masyrakat tidak panik dan tidak melakukan penjualan saham dengan pertimbangan yang tidak mumpuni karena di takutkan kepanikan ini akan berdampak semakin besarnya kemungkinan terjadinya Inflasi dengan waktu yang cepat dan efek paling buruknya terjadinya resesi global.

\section{KESIMPULAN DAN SARAN}

Pandemi COVID-19 sangat berdampak terhadap pergerakan indeks saham,termasuk dengan saham syariah di Indonesia. Hal ini mempengaruhi minat masyarakat domestik maupun masyarakat asing untuk menginvestasikan dananya di dalam pasar saham Indonesia. Karena Indonesia dianggap Pasar yang sedangdalam keadaan tidak stabil,akibat dari adanya penyebaran virus yg menghambat Produksi, Konsumsi dan distribusi komoditas pasar yang terjadi saat ini..Hasil analisis Trend menunjukkan pasar saham mengalami penurunan jika wabah ini tidak teratasi dengan baik oleh pengambil kebijakan.

Harapan dari penulis masyarakat yang memiliki saham sebaiknya tidak gegabah melakukan penjualan saham, karena pengamat saham menggap kerugian yang di akibatkan 
Jurnal Kompetitif : Media Informasi Ekonomi Pembangunan, Manajemen dan Akuntansi Vol. 6 No. 2, September 2020

oleh pandemicini hanya sementara waktu dan akan berakhirsaat pandemic ini berhenti atau terminimalisir dan keadaan pasar pun akan kembali normal. Penulis rekomendasikan utuk peneliti selanjutnya dapat melakukan penelitian terkait efek dari pandemicsetelah Covid-19 ini berlalu dan bagaima agar pasar saham tidak mengalami penurunan saat pandemicdi masa yang akan datang.

\section{DAFTAR PUSTAKA}

Ali Rama, (2013) Perbankan Syariah dan Pertumbuhan Ekonomi Indonesia, UIN Syarif Hidayatullah Jakarta, Signifikan Vol. 2 No. 1 April 2013. Hal 34

Makalah Presentasi Azis Budi Setiawan (Dosen STEI SEBI), Pandemic Covid dan UMKM

Muhammad Yafiz, (2008) Saham Dan Pasar Modal Syariah: Konsep, Sejarah Dan Perkembangannya.Fakultas Syariah IAIN Sumatera Utara, MIQOT Vol. XXXII No. 2 Juli-Desember 2008 .hal. 233

M. Nazir, Metode Penelitian, (Jakarta, Ghalia Indonesia, cet.ke-5, 2003), Hal 27

https://katadata.co.id, di akses 5 Mei 2020 pukul $21.00 \mathrm{Wib}$

https://idcloudhost.com, di akses 26 maret 2020

https://www.liputan6.com, di akses 5 Mei 2020

https://www.cnbcindonesia.com, Diakses 20 maret 2020

https://market.bisnis.com, di akses 4 Mei 23.00 wib

https://voi.id, di akses 5 Mei 2020 Pukul 22.00 Wib

https://www.kompas.com, di akses 8 Mei 2020

https://m.detik.com, di akses 3 Mei 2020 Pukul $22.00 \mathrm{Wib}$

https://news.detik.com, di akses 4 mei 23.00 wib

https://finansial.bisnis.com, di akses pada 04 Mei 2020 pukul 05.00 WIB

https://money.kompas.com, diakses pada 4 mei 2020 pukul 05.00 WIB

https://www.sentrarak.com, diakses 10 Mei 2020

https://market.bisnis.com, di akses 3 Mei 2020

https://investasi.kontan.co.id, diakses 31 Desember 2019 